\title{
ANALISIS PRODUKSI, KONSUMSI DAN PEMASARAN USAHATANI PADI DI DESA LEMBAH ASRI KECAMATAN WEDA SELATAN KABUPATEN HALMAHERA TENGAH
}

\author{
Haris Mahmud ${ }^{1}$, Suwandi S. Sangadji ${ }^{2}$, Suhardi $^{3}$ \\ Email : haris.mahmud128@ gmail.com \\ ${ }^{1,2}$ Program Studi Agribisnis, Fakultas Pertanian, Universitas Nuku \\ ${ }^{3}$ Program Studi Agribisnis, Fakultas Pertanian, Universitas Khairun
}

\begin{abstract}
The application of rice farming in North Maluku is a response to the record of future agriculture which is increasingly faced with scarce energy resources, the search for and the quality of food, feed, and environmentally friendly energy. The purpose of this study is to provide an overview of the existing agricultural conditions in North Maluku and to formulate steps for the transformation towards rice farming that will be achieved. The condition of rice farming in North Maluku is still at the agronomic level with minimum technology with low productivity indicators ( $<4$ tons / ha), farmer institutions in the beginner class, low group management and semi-subsistence farming orientation. The problems in the application of rice farming consist of technical and non-technical problems so that the application of the agricultural concept must be carried out in stages with the socio-economic and cultural conditions of the community. One of the important factors in producing food is the amount of land because land is the main production factor for producing food. Land is an economic resource whose population is relatively fixed but whose needs continue to increase due to development needs. In addition, land also has specific characteristics (topography, slope, soil texture, chemical content.)
\end{abstract}

Key words: Rice, Production, North Maluku

\section{A. PENDAHULUAN}

Pangan merupakan kebutuhan dasar manusia yang paling utama dan pemenuhannya merupakan bagian dari hak asasi manusia yang dijamin di dalam UUD 1945 sebagai komponen dasar untuk mewujudkan sumber daya manusia yang berkualitas. Dengan demikian pemenuhan kecukupan pangan bagi seluruh rakyat merupakan kewajiban, baik secara moral, sosial, maupun hukum. Amanat Undang Undang No 18 Tahun 2012 tentang Pangan secara tegas mengemukakan perlunya dibangun ketahanan pangan yang mandiri dan berdaulat. Hal ini antara lain oleh kondisi dasar negara Indonesia sebagai negara kepulauan yang sangat luas dan berpenduduk besar, sehingga kepentingan penyediaan pangan yang cukup dan dapat diakses oleh seluruh rumahtangga setiap saat menjadi sangat strategis, dari aspek sosiologis, politis dan yuridis. Sejalan dengan aspek strategis tersebut, maka upaya untuk membangun ketahanan dan kemandirian pangan yang kokoh selalu menjadi fokus pembangunan pertanian nasional dari sejak penjajahan, orde lama, orde baru dan era reformasi sampai saat ini. 
Ketersediaan pangan yang cukup merupakan prasyarat terbangunnya kemandirian pangan. Ketersediaan pangan tersebut harus dibangun atas dasar kemampuan produksi dalam negeri (swasembada) melalui optimalisasi seluruh potensi di dalam negeri. Untuk itu, upaya untuk meningkatkan kapasitas produksi pangan dari dalam negeri perlu terus dilakukan. Hasil diidentifikasi tersebut merupakan dasar bagi kegiatan perumusan dan pelaksanaan program produksi pangan secara spesifik.

Padi adalah salah satu komoditas strategis saat ini yang belum mengalami pengolahan secara signifikan oleh produsen sebelum dipasarkan.Perlakuan pasca panen misalnya pengeringan hingga kadar air tertentu sudah dianggap cukup untuk memasarkan produk pertanian bahkan banyak petani padi menjual hasil panennya dalam bentuk gabah kering panen (GKP) dengan alasan tidak ada tempat untuk menjemur atau mengeringkan dan juga karena kebutuhan uang tunai yang mendesak.

Subsistem pemasaran pangan dan produk pertanian terdiri atas empat bagian yaitu produksi, distribusi, konsumsi, dan peraturan. Pelaku utama dalam rantai kegiatan yang menghubungkan pangan dan pertanian adalah petani (atau nelayan, peternak), perantara, pengolah pangan, dan konsumen. Prakteknya mereka memandang pemasaran pangan/produk pertanian sesuai kepentingan masing-masing. Pada taraf tertentu kepentingan mereka saling bertentangan.

Fokus utama petani adalah memproduksi sebanyak-banyaknya dengan harga setinggi mungkin. Sebaliknya, pengolah produk, pedagang pengumpul dan pengecer, serta konsumen menghendaki harga beli rendah dengan kualitas tinggi. Jelas di sini ada perbedaan kepentingan antar berbagai pihak. Perlu kemitraan antar empat pelaku pemasaran ini karena satu dengan yang lain saling membutuhkan. Dalam jangka panjang semua akan salingtergantung dan bisa bertahan jika masing-masing merasa diuntungkan. Jika suplai dalam negeri tidak lagi mencukupi karena petani kurang insentif untuk memproduksi maka akan terjadi impor. Suplai dari impor untuk memenuhi kebutuhan pasar domestik pada taraf tertentu diperlukan, tetapi disisi lain dapat menekan petani.

Kinerja pemasaran produk pertanian yang baik, khususnya pangan akan mendorong petani menghasilkan pangan melebihi kebutuhan rumah tangga. Petani akan memasarkan sebagian produksinya setelah dikurangi untuk kebutuhan konsumsi rumah tangga. Hasil panen yang dijual digunakan oleh petani untuk membayar tenaga kerja, sarana produksi, sewa lahan maupun kebutuhan 
seharihari. Pemasaran juga memberi insentif kepada petani agar menghasilkan produk sesuai kebutuhan konsumen serta mengikuti standar pemasaran yang berlaku. Bahkan petani bersedia memproduksi pangan yang bukan merupakan pangan pokok karena produknya laku dijual dan menguntungkan.

Kinerja pemasaran diukur dari keuntungan yang diperoleh produsen (petani) atau persentase harga yang diterima petani dibanding harga eceran, efisiensi rantai pemasaran, dan keterjangkauan harga produk oleh konsumen. Intervensi pemerintah dapat mempengaruhi kinerja pasar. Untuk komoditas pangan yang bersifat strategis, intervensi pemerintah umumnya dapat membuat kinerja pasar menjadi lebih baik.

Produksi padi di Maluku Utara berdasarkan ARAM II tahun 2015 mencapai 77096 ton atau sebesar tumbuh sebesar 4,26\% per tahun. Pertumbuhan ini lebih banyak di dorong oleh luas panen seluas 22078 ha atau tumbuh sebesar 4,09 \% per tahunnya dibandingkan produktivitas sebesar 3,49 t/ha atau meningkat sebesar $0,13 \%$ per tahun (Gambar 1). Hal ini mengindikasikan bahwa penerapan teknologi padi di Maluku Utara masih sangat terbatas mengingat produktivitas nasional sudah mencapai 5,3 ton/ha dan potensi hasil kajian di Maluku Utara bisa mencapai 9,1 ton/ha untuk padi sawah (BPTP Maluku Utara,
2015). Menurut Darwanto (2010), untuk meningkatkan produktivitas lahan pertanian maka diperlukan kombinasi penggunaan tenaga kerja, benih, pupuk, pengolahan lahan dan perawatan yang maksimal serta penggunaan modal dan teknologi yang tepat.

Produksi padi di Maluku Utara masih bertumpu pada lahan sawah. Padi sawah masih menjadi kontributor utama sebesar 83,4\% sedangkan padi ladang hanya $16,6 \%$. Jika di pulau jawa luas lahan sawah semakin lama semakin berkurang maka di Maluku Utara luas sawah terus meningkat $12,2 \%$ tiap tahunnya. Pada tahun 2011 luas sawah sebesar 9044 ha, kemudian di tahun 2012 terdapat percetakan sawah baru seluas 2545 ha, tahun 2013 sebesar 704 ha, dan ditahun 2014 percetakan sawah hanya 300 ha (Tabel 2). Percetakan sawah baru pada prinsipnya belum bisa langsung mendongkrak produktivitas padi mengingat lahan sawah bukaan baru masih memiliki banyak keterbatasan sifat fisik, mekanik, maupun kimia tanah. Menurut Hartatik dkk (2010), pembukaan sawah baru akan menghadapi masalah kesuburan yang masih rendah maupun keracunan $\mathrm{Fe}$ bagi padi sehingga dibutuhkan perbaikan lingkungan tumbuh tanaman dengan teknologi irigasi intermitten untuk mencuci kadar Fe, ameliorasi dengan pemberian kapur/dolomit, dan bahan organik, serta penambahan pupuk urea, SP36, 
dan $\mathrm{KCl}$ untuk meningkatkan status hara dalam tanah serta mencukupi kebutuhan hara tanaman.

Permodalan merupakan salah satu faktor produksi penting dalam usaha pertanian. Namun, dalam operasional usahanya tidak semua petani memiliki modal yang cukup. Aksesibilitas petani terhadap sumber-sumber permodalan masih sangat terbatas, terutama bagi petani-petani yang menguasai lahan sempit yang merupakan komunitas terbesar dari masyarakat perdesaan (Nurmanaf, 2007). Program pemerintah khusus untuk pembiayaan petani salah satunya adalah Pengembangan Usaha Agribisnis Perdesaan (PUAP). Program PUAP yang sudah dimulai dari tahun 2008 hingga sekarang mensyaratkan terbentuk dan berkembangnya LKM-A di desa sasaran PUAP sebagai lembaga yang dapat membantu memfasilitasi permodalan usahatani bagi petani di perdesaan (Saleh et al., 2013). Program PUAP di Maluku Utara telah berdampak pada peningkatan jumlah kelembagaan Gapoktan, sampai tahun 2015 tercatat sebanyak 663 Gapoktan PUAP yang telah dibentuk dari tahun 2008-2015 dengan beragam pengembangan usaha agribisnisnya. Berikut ini jenis usaha yang dikembangkan oleh Gapoktan PUAP di Maluku Utara. Gambar 3 menjelaskan bahwa pengembangan usaha Gapoktan PUAP sebagian besar pada usaha off farm (34,78 persen) dan tanaman pangan (30,99 persen). Untuk tanaman pangan, pembiayaan usaha dari program PUAP untuk komoditas tanaman padi masih tergolong kecil, yakni hanya 11,44 persen dari pembiayaan total untuk usaha tanaman pangan di Maluku Utara (Syukur et al., 2014).

Berdasarkan latar belakang yang telah dikemukakan, maka permasalahan yang menjadi fokus penelitian ini adalah Berapa jumlah produksi padi permusim tanam, Berapa besar jumlah produksi padi yang dikonsumsi dan yang dijual dan Bagaimana model rantai pemasaran beras. Tujuan yang ingin dicapai dalam penelitian ini adalah untuk Mengetahui jumlah produksi padi permusim tanam, Menganalisis produksi padi yang dikonsumsi dan yang dijual oleh petani. dan Menganalisis mata rantai pemasaran beras.

\section{B. METODE PENELITIAN}

Penelitian ini dilaksanakan di Desa Lembah Asri, Kecamatan Weda Selatan, Kabupaten Halmahera Tengah, Provinsi Maluku Utara. Peneliti memilih lokasi tersebut karena lokasi tersebut memiliki potensi sebagai penghasil padi. Penelitian ini dilaksanakan pada bulan Agustus sampai bulan September 2020.

Populasi dalam penelitian ini adalah petani ( pemilik ) yang berada di Desa Lembah Asri Kecamatan Weda Selatan Kabupaten 
Halmahera Tengah yang berjumlah 182orang dan sampel dalam penelitian ini ditentukan secara acak,sebesar $15 \%$ dari populasi sehingga sampel berjumlah 27 orang.

Sumber data yang digunakan dalam penulisan jurnal ini adalah data primer yaitu data yang diperoleh dari responden melalui wawancara langsung dengan menggunakan kuesioner yang telah disiapkan. Data primer yang diperlukan selama penelitian berupa identitas responden, jumlah pendapatan, kebiasaan/pola makan, jenis beras yang dikonsumsi, jumlah total produksi padi, jumlah konsumsi beras dan lain-lain. Data sekunder yaitu data yang diperoleh dari instansi terkait, berupa kantor di Desa Lembah Asri Kecamatan Weda Selatan Kabupaten Halmahera Tengah, Dinas pertanian Kabupaten Halmahera Tengah, Badan Statistik Kabupaten Halmahera Tengah. Data sekunder yang dibutuhkan dalam penelitian ini antara lain : jumlah produksi dan konsumsi pada suatu daerah, jumlah penduduk keseluruhan, data kependudukan, kondisi suatu daerah, dan lain-lain.

Berdasarkan data yang diperoleh dari penelitian ini selanjutnya akan ditabulasi dan diolah dengan menggunakan analisis Untuk mencapai tujuan pertama dan kedua maka digunakan analisis deskriktif kuantitatif guna mengetahui jumlah produksi yang dikonsumsi dan yang dijual oleh keluarga petani. Jumlah produksi akan memperhatikan produktifitas lahan dan penerimaan usahatani dengan menggunakan rumus analisis pendapatan sebagai berikut (Soekartawi dalam Hasminar, 2014).

\section{HASIL DAN PEMBAHASAN}

Umur merupakan salah satu faktor yang dapat mempengaruhi keberhasilan dalam mengelola suatu usaha. Petani yang berusia muda dan sehat mempunyai kemampuan fisik dan lebih cepat menerima teknologi yang dianjurkan. Sebaliknya petani yang berusia tua mempunyai banyak pertimbangan dalam menerima teknologi baru.

Informasi umur yang di dapat di lapangan memperlihatkan bahwa umumnya petani berada dalam rentang umur 35-44 (40,74\%). Kelompok umur 55 tahun ketas merupakan petani yang paling sedikit $(22,22 \%)$. Dilihat dari sebaran umur, tampaknya petani di Desa Baru Kecamatan Luyo berada dalam usia yang produktif. Diketahui bahwa umur tersebut dapat menerima inovasi teknologi pertanian dan juga mereka masih memiliki tanggungan keluarga yang sebagian besar masih bersekolah.

Pendidikan petani yang didapatkan pada penelitian memperlihatkan bahwa lebih dari hampir 75 persen petani di desa Lembah Asri Kecamatan Weda Selatan berpendidikan rendah (74.1 persen). Keadaan Pendidikan 
petanirespondenpada tingkat SD menempati angka tertinggi yakni 15 jiwa $(55,55 \%)$, sedangkan pada tingkat SMA sebanyak 7 jiwa $(25,92 \%)$, dan yang terendah adalah pada tingkat SMP sebanyak 5 jiwa (\%), hal ini berarti rata - rata pendidikan di daerah ini masih perlu ditingkatkan.

Pekerjaan tambahan dari beberapa responden sebagai seorang wiraswasta ini adalah seseorang yang mempunyai berbagai macam pekerjaan. Pekerjaan took campuranini juga adalah pekerjaan salah satu responden yang memiliki berbagai macam jenis barang yang dijual dan memiliki pendapatan yang cukup besar yaitu sebesar Rp.10.000.000 perbulan. Toko/Bengkel juga adalah pekerjaan yang dimiliki salah satu responden dan memiliki pendapatan yang sangat tinggi yaitu sebesar Rp.15.000.000 perbulan, awalnya bengkel tersebut adalah bengkel sepeda tetapi dari tahun ketahun pendapatannya terus meningkat dan akhirnya menjadi bengkel motor yang mempunyai banyak pelanggang.

Pekerjaan tambahan sebagai penjual nasi kuning yang dimaksud adalah seorang janda dan sekaligus kepala rumah tangga yang menafkahi 1 orang anak, pekerjaan tersebut digeluti karena tidak memiliki modal yang cukup besar, pekerjaannya tidak terlalu berat bagi seorang janda dan pendapatan dari menjual nasi kuning tersebut cukup untuk memenuhi kebutuhannya setiap hari. Dari 27 responden ada 2 responden yang tindak memiliki pekerjaan tambahan.

Unsur hara yang tersedia dalam tanah saja belum mencukupi bagi sepanjang pertumbuhan padi. Untuk menyediakan zat hara yang optimal bagi pertumbuhan padi, maka petani menambahkan dari luar melalui pemupukan pada tanaman padi dilakukan setelah penanaman. Jumlah pupuk yang digunakan tergantung dari luas lahan, pengalaman dan kemampuan ekonomi petani, jenis pupuk yang digunakan petani padi di Desa Baru adalah Urea dan NPK Phonska. Penggunaan pupuk ini berbeda-beda oleh setiap responden tergantung dengan luasan lahan tanaman padi.

Penyakit dan hama adalah kerusakankerusakan pada tanaman yang disebabkan oleh berbagai macam virus dan bakteri, kerusakan pada tanaman akibat penyakit bisa mendatangkan kerugian besar jika tidak diantisipasi, demikian pula halnya dengan hama juga merupakan salah satu faktor penyebab rusaknya tanaman. Untuk mengantisipasi hal tersebut maka petani padi di desa baru menggunakan pestisida. Penggunaan pestisida pada tanaman padi dimaksudkan untuk menanggulangi hama dan penyakit pada tanaman baik yang belum berproduksi maupun yang telah berproduksi. Namun pemberian pestisida harus memperhatikan dosis 
penggunaan serta cara penggunaannya. Ada beberapa jenis pestisida yang sering digunakan oleh petani padi seperti spontan, metacolor, hiponararel, josepat, gandasil, sempurna, prapaton, score, explore, laser, polisa dan domindo.

Produksi padi yang dihasilkan dalam 3 kali panen oleh setiap petani bervariasi, hal ini disebabkan oleh adanya berbagai macam perbedaan luas lahan, tingkat kesuburan tanah, pemakaian pupuk dan obat-obatan serta penggunaan bibit.

Biaya tetap adalah biaya pengeluaran yang tidak tergantung pada perubahan hasil produksi yang dihasilkan. Adapun biaya tetap yang yang dimaksud seperti PBB, cangkul, sabit, parang, ember, handsprayer dan bajak sedangkan Biaya variabel merupakan biaya yang dapat berubah mengikuti besar kecilnya produksi atau biaya yang habis terpakai dalam sekali produksi. Adapun biaya tidak tetap yang dikeluarkan petani padi selama proses produksi.

Berdasarkan hasil penelitian yang dilakukan, diketahui bahwa ada tigamodel saluran pemasaran padi di Desa Lembah Asri Kecamatan Weda Selatan Kabupaten Halmahera Tengah. Adapun ketiga model tersebut adalah sebagai berikut : 1. Saluran Pemasaran I Pedagang pengumpul $\rightarrow$ Pedagang Besar $\rightarrow$ Pedagang Pengecer. Sistem pemasaran ini dilakukan oleh responden petani padi, dimana petani menjual hasil produksinya kepada pedagang pengumpul setelah itu pedagang pengumpul menjualnya kembali ke Pedagang besar yang ada di Kabupaten Halmahera Tengah dan kemudian dijual ke Pedagang Pengecer dan terakhir ke Konsumen Dari petani sampai ke pedagang pengumpul dan pedagang besar yang dijual masih berupa gabah sedangkan dari pedagang besar ke konsumen yang dijual sudah berupa beras.

\section{KESIMPULAN}

Berdasarkan hasil penelitianyang dilakukan pada petani padi di Desa Lembah Asri Kecamatan Weda Selatan Kabupaten Halmahera Tengah tentang analisis produksi, konsumsi dan pemasaran usahatani padi dapat diambil beberapa kesimpulan sebagai berikut :

1. Rata-rata pendapatan petani padi sebesar Rp.7.865.819

2. Pemanfaatan produksi padi terbagi atas dua yaitu untuk di konsumsi dan untuk dijual. Adapun rata-rata pemanfaatan produksi padi untuk konsumsi yaitu sebesar $1.022 \mathrm{Kg}$ (32\%) sedangkan rata-rata pemanfaatan produksi padi untuk dijual sebesar $2.180 \mathrm{Kg}$ (68\%).

3. Terdapat Tiga model saluran pemasaran yang ada di Desa Lembah Asri Kecamatan Weda Selatan Kabupaten Halmahera Tengah. Ketiga merupakan pemasaran tidak 
langsung yang melibatkan pedagang pengumpul, pedagang besar dan pedangang pengecer.

4. Margin keuntungan yang diperoleh berbedabeda setiap saluran. Margin keuntungan pada saluran I sebesar Rp.2.760, saluran II Rp.2880 dan pada saluran III sebesar Rp.2.360. Margin tertinggi diperoleh pada saluran II.

\section{DAFTAR PUSTAKA}

Darwanto. 2010. Analisis Efisiensi Usahatani Padi Di Jawa Tengah (Penerapan Analisis Frontier). Jurnal Organisasi dan Manajemen, Vol. 6(1): 46-57.

Hartatik, W. Sulaeman, dan A. Kasno. 2010. Perubahan sifat kimia tanah dan ameliorasi sawah bukaan baru. Dalam Buku Tanah Sawah Bukaan Baru. Balai Besar Litbang Sumberdaya Lahan Pertanian. Bogor. Hal: 53-76

Nurmanaf, A. R. 2007. Lembaga Informal Pembiayaan Mikro Lebih Dekat Dengan Petani. Jurnal Analisis Kebijakan Pertanian Volume 5 No. 2, Juni 2007: 99-109.

Pasandaran, E. 2015. Memperkuat Kemampuan Swasembada Pangan. IAARD Press, Jakarta.

Saleh, Yopi, C. Sugihono, dan V. W. Hanifah. Kinerja Lembaga Keuangan Mikro Agribisnis Di Kabupaten Bantul Provinsi Yogyakarta. Jurnal Pengkajian Dan Pengembangan Teknologi Pertanian Vol. 16, No. 3, November 2013: 212-222.

Syukur, Muhammad, dkk. 2014. Laporan Akhir Pendampingan Program Pengembangan Usaha Agribisnis Perdesaan di Maluku Utara. Laporan Akhir. BPTP Maluku Utara. Sofifi. 